\title{
A Simple, Fast, and Inexpensive Simultaneous Determination of Trace Bismuth(III) and Lead(II) in Water Samples by Adsorptive Stripping Voltammetry
}

\author{
Malgorzata Grabarczyk and Marzena Adamczyk \\ Department of Analytical Chemistry and Instrumental Analysis, Faculty of Chemistry, Maria Curie-Sklodowska University, \\ 20-031 Lublin, Poland \\ Correspondence should be addressed to Malgorzata Grabarczyk; mgrabarc@poczta.umcs.lublin.pl
}

Received 12 June 2017; Accepted 25 July 2017; Published 28 August 2017

Academic Editor: Bengi Uslu

Copyright (C) 2017 Malgorzata Grabarczyk and Marzena Adamczyk. This is an open access article distributed under the Creative Commons Attribution License, which permits unrestricted use, distribution, and reproduction in any medium, provided the original work is properly cited.

A simple, fast, and inexpensive voltammetric method for the simultaneous determination of trace bismuth(III) and lead(II) using $(\mathrm{Hg}(\mathrm{Ag}) \mathrm{FE})$ as a working electrode was optimized. For adsorptive stripping voltammetric determination of $\mathrm{Bi}(\mathrm{III})$ and $\mathrm{Pb}(\mathrm{II})$ in a single scan, the cupferron was applied as a complexing agent. Experimental conditions under which these elements can be simultaneously detected include $0.1 \mathrm{~mol} \mathrm{~L}^{-1}$ acetate buffer $(\mathrm{pH}=4.6), 1 \times 10^{-4} \mathrm{~mol} \mathrm{~L}^{-1}$ cupferron, accumulation potential $-0.05 \mathrm{~V}$, and accumulation time $30 \mathrm{~s}$. The experiments were performed without deaeration of the solutions. The calibration graph was linear from $2 \times 10^{-9} \mathrm{~mol} \mathrm{~L}^{-1}$ to $1 \times 10^{-7} \mathrm{~mol} \mathrm{~L}^{-1}$ for the simultaneous presence of bismuth and lead. The detection limits for preconcentration time of $30 \mathrm{~s}$ were $6.7 \times 10^{-10} \mathrm{~mol} \mathrm{~L}$ and $8.8 \times 10^{-10} \mathrm{~mol} \mathrm{~L}^{-1}$ for bismuth and lead, respectively. The application of this procedure was tested by analyzing certified reference material (SPS-WW1 Wastewater) and Lake Zemborzyce water (eastern areas of Poland).

\section{Introduction}

The scope for a simultaneous determination of two or more metals at ultratrace levels has always awaken interest in natural water samples analysis [1]. One of the most appropriate techniques that makes possible the determination of very low concentrations and simultaneous determination of several elements in one measurement is stripping voltammetry. Hence, in recent years, a lot of voltammetric procedures for the simultaneous determination of different metals have been reported in the literature [2-17]. As can be seen, in the case of simultaneous determination of bismuth with other elements, in the great majority, the procedures concern determination of bismuth with copper in one measurement [12-16]. As regards cadmium the simultaneous determination of this metal is connected with cadmium $[2,4-6]$. We have managed to find only one paper relating to simultaneous determination bismuth and lead [17].

Bismuth and lead are among the most interesting metals which have received extensive attention in the field of trace metal analysis. There is concern about the fact that bismuth has been exploited in many various areas of industry, for instance, in the chemical and metallurgical industries, in the production of low melting alloys and thermoelectric materials, in pharmaceutical industry, in the production of cosmetics, and in semiconductor devices such as CCDs or photodiodes [18-22]. Lead is also an important metal in many kinds of industrial processes. These heavy metals are introduced into the environment from a variety of human activities such as the manufacture of batteries, metal products, leaded gasoline, paints, and stabilizers for PVC, crystal glass, and ceramic glazes [23-26]. For this reason, bismuth and lead are considered to be anthropogenic pollutants of the environment, and so the monitoring of these elements is a very important issue. There are several methods which have been used for bismuth and lead determination including inductively coupled plasma emission spectrometry or mass spectrometry [27-29], flame, and electrothermal or hydride generation atomic absorption spectrometry [30-35]. The 
advantages of these methods are excellent sensitivity, good selectivity, and a wide linearity range, but, on the other hand, they require expensive instruments, so they may be prohibitive to many laboratories. Moreover separation from other elements present in the sample and also the use of a preconcentration is usually necessary.

The present paper describes a simple, fast, inexpensive and at the same time very sensitive procedure for the simultaneous determination of bismuth and lead in environmental water samples. Total measurement time is of about $30 \mathrm{~s}$ and the analyzed sample does not require any pretreatment and is added directly in its original form to the measurement cell. The scheme is built around the adsorptive stripping voltammetric method and is based on the accumulation of $\mathrm{Bi}(\mathrm{III})$ cupferron and $\mathrm{Pb}(\mathrm{II})$-cupferron complexes and following its reduction via the use of an appropriate variation of potential. A single potential scan allowed us to obtain qualitative and quantitative information about the trace bismuth and lead levels. The complexes of $\mathrm{Bi}$ (III)-cupferron and $\mathrm{Pb}$ (II)cupferron were accumulated due to their adsorption on a renewable mercury film silver based electrode $(\mathrm{Hg}(\mathrm{Ag}) \mathrm{FE})$ used as a working electrode. The $\mathrm{Hg}(\mathrm{Ag}) \mathrm{FE}$ electrode is a viable alternative to the hanging mercury drop electrode (HMDE) because it guarantees all advantages of the mercury electrode while at the same time thanks to its construction greatly reducing toxicity.

This work was optimized by a selection of optimum conditions including the selection of the supporting electrolyte, its $\mathrm{pH}$, concentration of the cupferron, and accumulation potential and time. The current study has a comparative advantage in relation to the only procedure of simultaneous determination bismuth and lead which we find in literature data [17]. These benefits are significantly lower detection limits, use of commonly available complexing agent, and above all application of more friendly for lab analysis and environment working electrode.

\section{Experimental}

2.1. Reagents and Solutions. A standard solution of $1 \mathrm{gL}^{-1}$ of $\mathrm{Pb}$ (II) was obtained from Fluka (Buchs, Switzerland). Standard solutions of $1 \mathrm{~g} \mathrm{~L}^{-1}$ of $\mathrm{Bi}(\mathrm{III})$ and cupferron $(\mathrm{N}$ nitrosophenylhydroxylamine ammonium salt) were obtained from Merck (Darmstadt, Germany). A $1 \mathrm{~mol} \mathrm{~L}^{-1}$ acetate buffer $(\mathrm{pH}=4.6)$ was prepared from Suprapur $\mathrm{CH}_{3} \mathrm{COOH}$ and $\mathrm{NaOH}$ obtained from Merck. Triton X-100, sodium dodecyl sulfate (SDS), and cetyltrimethylammonium bromide (CTAB) were purchased from Fluka. Humic acid sodium (HA) salt was obtained from Aldrich. The river fulvic acid (FA) and natural organic matter were a standard sample obtained from the Suwannee River and purchased from the International Humic Substances Society. Amberlite XAD-7 resin and Rhamnolipid (biosurfactant) were obtained from Sigma. Amberlite XAD-7 resin was washed four times in water and dried up at the temperature of $50^{\circ} \mathrm{C}$ before use. The standard material SPS-WW1 Batch 111-Reference Material for Measurement of Elements in Wastewaters was obtained from Spectrapure Standards, Oslo, Norway. All solutions were prepared using triply distilled water.
2.2. Apparatus. Voltammetric measurements were performed with a $\mu$ Autolab analyzer (Utrecht, Netherlands). The threeelectrode system was completed by a renewable mercury film silver based electrode $(\mathrm{Hg}(\mathrm{Ag}) \mathrm{FE})$ as a working electrode (its construction was described in an earlier paper [36]), platinum wire as an auxiliary electrode, and an $\mathrm{Ag} / \mathrm{AgCl}$ electrode as a reference electrode.

2.3. General Procedure. The analyzed solution or the synthetic solution (containing adequate levels of $\mathrm{Bi}(\mathrm{III})$ and $\mathrm{Pb}$ (II) in $0.1 \mathrm{~mol} \mathrm{~L}^{-1}$ nitric acid) used for optimization of procedure conditions was pipetted into the voltammetric cell. Next the acetate buffer, cupferron, and triply distilled water were introduced in order to obtain $10 \mathrm{~mL}$ of the solution containing $0.1 \mathrm{~mol} \mathrm{~L}^{-1}$ acetate buffer $(\mathrm{pH}=4.6), 1$ $\times 10^{-4} \mathrm{~mol} \mathrm{~L}^{-1}$ cupferron. Research showed that sequence of reagents addition could be random and did not affect voltammetric signal of bismuth and lead. The solution was not deaerated.

The measurements were performed by differential pulse adsorptive stripping voltammetry. The accumulation potential $-0.05 \mathrm{~V}$ was applied for $30 \mathrm{~s}$ while stirring the solution. At the end of accumulation time, the stirrer was switched off, and, after the equilibration time of $5 \mathrm{~s}$, a differential pulse voltammogram was recorded, while the potential was scanned from $-0.05 \mathrm{~V}$ to $-0.7 \mathrm{~V}$. The scan rate and pulse height were $20 \mathrm{mV} \mathrm{s}^{-1}$ and $-50 \mathrm{mV}$, respectively.

\section{Results and Discussion}

3.1. Conditions for Simultaneous Determination of Bi(III) and $\mathrm{Pb}(\mathrm{II})$. Preliminary works showed that cupferron was a suitable complexing agent for the determination of $\mathrm{Bi}$ (III) and $\mathrm{Pb}(\mathrm{II})$ when an acetate buffer was used as a supporting electrolyte $[37,38]$. Cupferron is commonly used in adsorptive voltammetric procedures as complexing agent, mainly applied under acidic conditions [9-11, 37-42]. The effect of $\mathrm{pH}$ of the buffer on the simultaneous determination of bismuth and lead was studied in the range from 3 to 6 . The acetate buffer and cupferron concentrations were $0.1 \mathrm{~mol} \mathrm{~L}^{-1}$ and $1 \times 10^{-4} \mathrm{~mol} \mathrm{~L}^{-1}$, respectively, and the concentration of metal ions was $2 \times 10^{-8} \mathrm{~mol} \mathrm{~L}^{-1}$, the deposition potential $-0.05 \mathrm{~V}$, and the deposition time $30 \mathrm{~s}$. The main factors which were taken into consideration were height and shape of bismuth and lead peaks and separation of the peaks. In the case of bismuth a variation of the $\mathrm{pH}$ in the whole verified range did not cause any significant change of the voltammetric signal. In the case of lead the signal remained constant in the range from 4 to 6 , for lower values it gradually decreased. Taking into account the above details as well as good buffering capacity, a pH value of 4.6 was chosen for the whole study.

The dependence between the $\mathrm{Bi}(\mathrm{III})$-cupferron and $\mathrm{Pb}$ (II)-cupferron peak currents on the complexing agent concentration was tested. The concentration of cupferron ranged from $1 \times 10^{-6} \mathrm{~mol} \mathrm{~L}^{-1}$ to $5 \times 10^{-4} \mathrm{~mol} \mathrm{~L}^{-1}$ in the presence of $2 \times 10^{-8} \mathrm{~mol} \mathrm{~L}^{-1}$ of each of metal ions and $0.1 \mathrm{~mol} \mathrm{~L}^{-1}$ acetate buffer $(\mathrm{pH}=4.6)$. The obtained results showed that the peak currents of both $\mathrm{Bi}(\mathrm{III})$-cupferron and $\mathrm{Pb}$ (II)-cupferron 


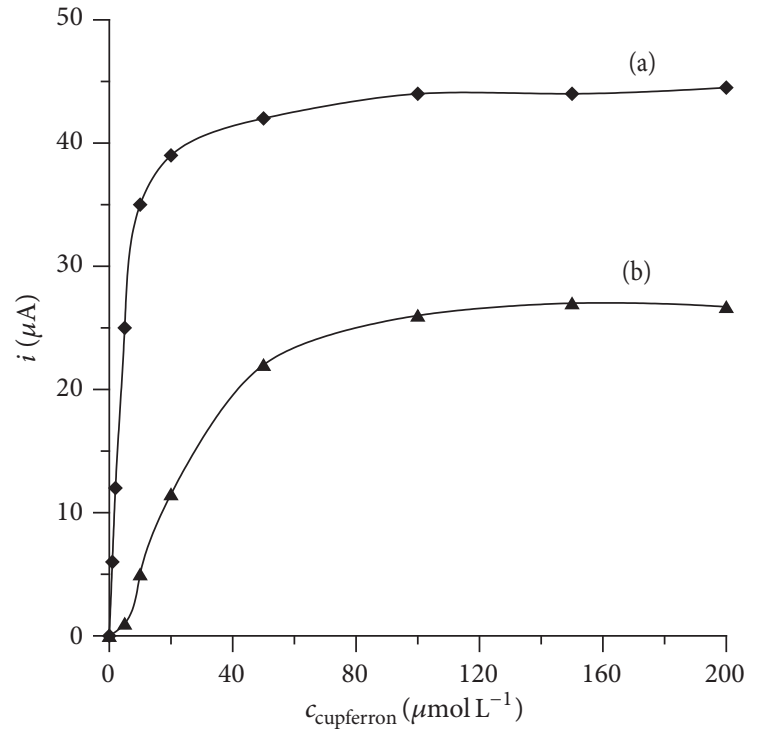

FIGURE 1: The influence of cupferron concentration on the $2 \times$ $10^{-8} \mathrm{~mol} \mathrm{~L}^{-1} \mathrm{Bi}$ (III) (a) and $2 \times 10^{-8} \mathrm{~mol} \mathrm{~L}^{-1} \mathrm{~Pb}$ (II) (b) peak current. Accumulation potential $-0.05 \mathrm{~V}$ and accumulation time $30 \mathrm{~s} . \mathrm{pH}$ acetate buffer equal to 4.5 .

increase with the increase of the complexing agent concentration up to $1 \times 10^{-4} \mathrm{~mol} \mathrm{~L}^{-1}$ (Figure 1).

The effect of the accumulation potential on the peak currents over the range of $0.2 \mathrm{~V}$ to $-0.3 \mathrm{~V}$ for $2 \times 10^{-8} \mathrm{~mol} \mathrm{~L}^{-1}$ $\mathrm{Bi}(\mathrm{III})$ and $\mathrm{Pb}(\mathrm{II})$ showed that the peak current for $\mathrm{Bi}(\mathrm{III})$ was almost stable in the whole range with a slight tendency to decrease for a more negative potential and the peak current for $\mathrm{Pb}$ (II) attained a maximum at the potential of about $-0.05 \mathrm{~V}$. So the accumulation potential equal to $-0.05 \mathrm{~V}$ was selected for further experiments, as the most suitable for both metal ions (Figure 2).

The effect of accumulation time on peak currents was examined in the $0-80 \mathrm{~s}$ range, while other standard measuring conditions remained constant as described above. The values of the voltammetric peak currents increased when accumulation time was prolonged to $30 \mathrm{~s}$ and $60 \mathrm{~s}$ for lead and bismuth, respectively (Figure 3).

3.2. Linear Ranges and Detection Limits. Linear ranges and detection limits for the simultaneous determination of bismuth and lead were evaluated under the selected conditions: $0.1 \mathrm{~mol} \mathrm{~L}^{-1}$ acetic buffer $(\mathrm{pH}=4.6), 1 \times 10^{-4} \mathrm{~mol} \mathrm{~L}^{-1}$ cupferron, accumulation potential $-0.05 \mathrm{~V}$, and accumulation time $30 \mathrm{~s}$. Linear calibration graphs were obtained in the concentration range of $2 \times 10^{-9} \mathrm{~mol} \mathrm{~L}^{-1}$ to $1 \times 10^{-7} \mathrm{~mol} \mathrm{~L}^{-1}$ for the simultaneous presence of $\mathrm{Bi}(\mathrm{III})$ and $\mathrm{Pb}$ (II) in the solution. They obeyed the following calibration equations: $y=1.97 x+3.05$ (for $\mathrm{Bi}(\mathrm{III})$ ) with the linear correlation coefficient $r=0.996$, and $y=1.20 x+1.41$ (for $\mathrm{Pb}(\mathrm{II})$ ) with the linear correlation coefficient $r=0.995$, where $y$ and $x$ are the peak current $(\mu \mathrm{A})$ and concentration $\left(\mathrm{nmol} \mathrm{L}{ }^{-1}\right)$, respectively. The detection limits estimated from three times the standard deviation of low $\mathrm{Bi}(\mathrm{III})$ and $\mathrm{Pb}(\mathrm{II})$

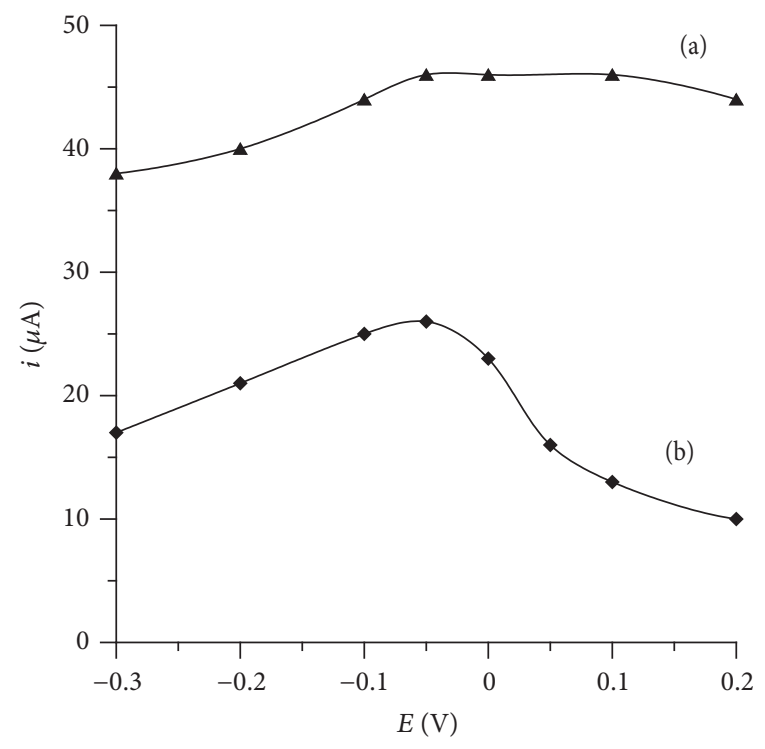

FIgURE 2: The influence of accumulation potential on the $2 \times$ $10^{-8} \mathrm{~mol} \mathrm{~L}^{-1} \mathrm{Bi}(\mathrm{III})$ (a) and $2 \times 10^{-8} \mathrm{~mol} \mathrm{~L}^{-1} \mathrm{~Pb}$ (II) (b) peak current. Concentration of cupferron $1 \times 10^{-4} \mathrm{~mol} \mathrm{~L}^{-1}$ and acetate buffer $0.1 \mathrm{~mol} \mathrm{~L}^{-1}(\mathrm{pH}=4.5)$. Accumulation time $30 \mathrm{~s}$.

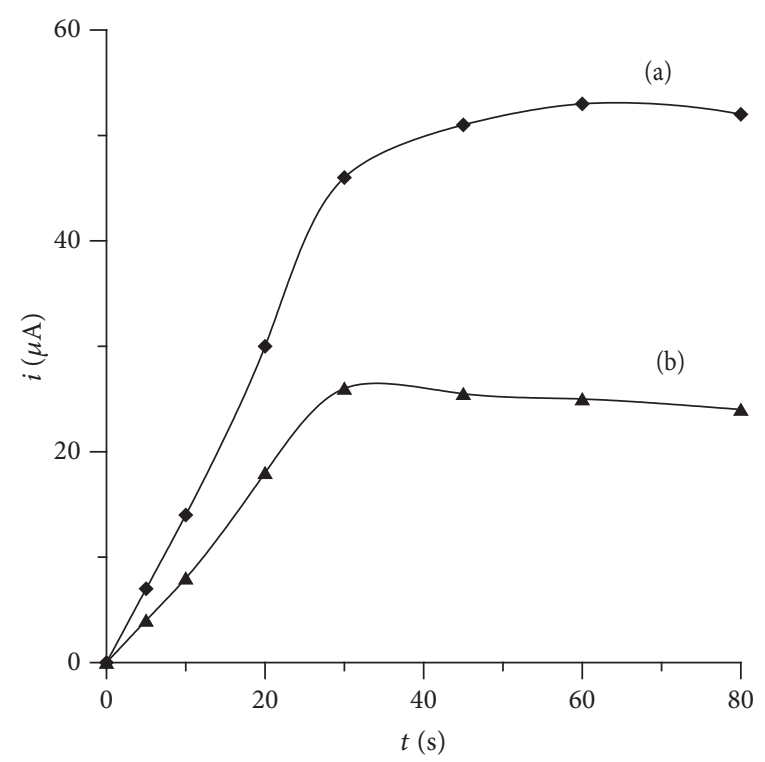

FIGURE 3: The influence of accumulation time on the $2 \times 10^{-8} \mathrm{~mol} \mathrm{~L}^{-1}$ $\mathrm{Bi}$ (III) (a) and $2 \times 10^{-8} \mathrm{~mol} \mathrm{~L}^{-1} \mathrm{~Pb}$ (II) (b) peak current. Concentration of cupferron $1 \times 10^{-4} \mathrm{~mol} \mathrm{~L}^{-1}$ and acetate buffer $0.1 \mathrm{~mol} \mathrm{~L}^{-1}(\mathrm{pH}$ $=4.5$ ). Accumulation potential $-0.05 \mathrm{~V}$.

concentrations and accumulation time $30 \mathrm{~s}$ were about 6.7 $\times 10^{-10} \mathrm{~mol} \mathrm{~L}^{-1}$ and $8.8 \times 10^{-10} \mathrm{~mol} \mathrm{~L}^{-1}$, respectively. The relative standard deviations (RSD) from six determinations at the concentrations $5 \times 10^{-9} \mathrm{~mol} \mathrm{~L}^{-1}$ of $\mathrm{Bi}(\mathrm{III})$ and $\mathrm{Pb}$ (II) were $3.9 \%$ and $5.0 \%$, respectively.

3.3. Interference of Organic Compounds. The aim of the proposed procedure was to analyze environmental water samples, so the influence of organic compounds present 


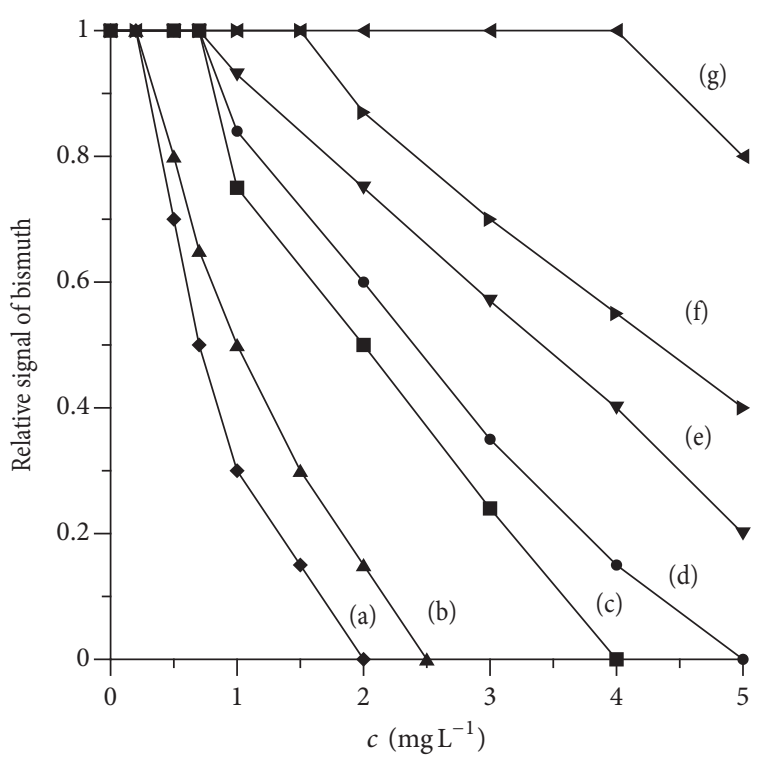

Figure 4: The influence of Triton X-100 (a), Rhamnolipid (b), HA (c), CTAB (d), FA (e), NOM, (f) and SDS (g) on $2 \times 10^{-8} \mathrm{~mol} \mathrm{~L}^{-1}$ $\mathrm{Bi}$ (III) peak current. Concentration of cupferron $1 \times 10^{-4} \mathrm{~mol} \mathrm{~L}^{-1}$ and acetate buffer $0.1 \mathrm{~mol} \mathrm{~L}^{-1}(\mathrm{pH}=4.5)$. Accumulation potential $-0.05 \mathrm{~V}$ and accumulation time $30 \mathrm{~s}$.

in natural samples such as surface active substances and humic substances should be taken into account. As it was proved in the previous procedures using HMDE as a working electrode and cupferron as a complexing agent, the organic compounds seriously suppress particularly the voltammetric signal of bismuth [37]. In the case of lead, the interference of organic substances was lower [38]. In the proposed procedure using $\mathrm{Hg}(\mathrm{Ag}) \mathrm{FE}$ as a working electrode, the influence of surface active substances, such as Triton X-100 (nonionic surfactant), sodium dodecyl sulfate (SDS, anionic surfactant), cetyltrimethylammonium bromide (CTAB, cationic surfactant), and Rhamnolipid (biosurfactant) and humic substances, such as humic acids (HA), fulvic acids (FA), and natural organic matter (NOM), was examined. No significant effect of surface active substances on the peak of lead was observed, their concentrations being no less than $5 \mathrm{ppm}$ did not interfere. In the case of humic substances, the permitted levels reached $2 \mathrm{ppm}$. The influence of organic substances on the bismuth signal was more noticeable and is presented in Figure 4. The organic substances clearly reduced the voltammetric signal, particularly in the case of bismuth. In order to analyze natural samples rich in organic matter the preliminary mixing of the analyzed sample with Amberlite XAD-7 resin is recommended as an efficient and well known [39-42] way to eliminate organic interferences.

3.4. Analysis of Certified Reference Material. Much to our regret, the certified reference material with environmental water matrices containing both bismuth and lead at low concentrations was unreachable. So the proposed method was tested by analysis of the certified reference material SPSWW1 Wastewater (Batch 111) containing trace elements such

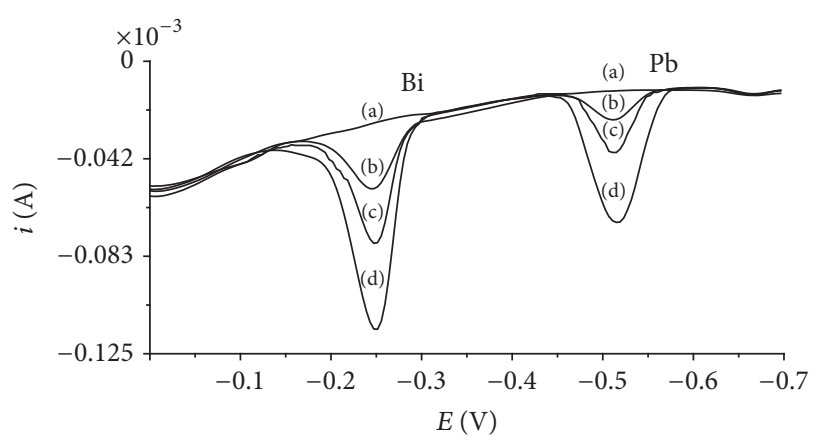

FIGURE 5: Differential pulse voltammograms obtained in the course of the $\mathrm{Bi}(\mathrm{III})$ and $\mathrm{Pb}$ (II) determination in Lake Zemborzyce water: (a) Lake Zemborzyce water diluted two times; (b) as (a) $+1 \times$ $10^{-8} \mathrm{~mol} \mathrm{~L}^{-1} \mathrm{Bi}(\mathrm{III})$ and $\mathrm{Pb}(\mathrm{II})$; (c) as (a) $+2 \times 10^{-8} \mathrm{~mol} \mathrm{~L}^{-1} \mathrm{Bi}(\mathrm{III})$ and $\mathrm{Pb}(\mathrm{II})$; (d) as (a) $+4 \times 10^{-8} \mathrm{~mol} \mathrm{~L}^{-1} \mathrm{Bi}$ (III) and $\mathrm{Pb}$ (II). Concentration of cupferron $1 \times 10^{-4} \mathrm{~mol} \mathrm{~L}^{-1}$ and acetate buffer $0.1 \mathrm{~mol} \mathrm{~L}^{-1}$ $(\mathrm{pH}=4.5)$. Accumulation potential $-0.05 \mathrm{~V}$ and accumulation time $30 \mathrm{~s}$.

as $\mathrm{Al}, \mathrm{As}, \mathrm{Cd}, \mathrm{Co}, \mathrm{Cr}, \mathrm{Cu}, \mathrm{Fe}, \mathrm{Mn}, \mathrm{Ni}, \mathrm{P}, \mathrm{Pb}, \mathrm{V}$, and $\mathrm{Zn}$ with the certified value $100.0 \pm 0.5 \mathrm{ng} \mathrm{mL}^{-1}$. As regards bismuth, it was additionally spiked with the same concentration. Three replicate determinations using the standard addition method were performed giving the values $96.2 \pm 0.6 \mathrm{ng} \mathrm{mL}^{-1}$ and $94.8 \pm 0.4 \mathrm{ng} \mathrm{mL}^{-1}$ for bismuth and lead, respectively. The measurements were performed using standard conditions but given the fact that the solution of the certified reference material SPS-WW1 contains nitric acid, a proper quantity of sodium hydroxide was additionally added in order to neutralize $\mathrm{pH}$.

Additional in order to demonstrate the applicability and reliability of the presented procedure for real water samples, Lake Zemborzyce (eastern areas of Poland) water was analyzed. The voltammograms recorded for this one did not exhibit any signals of $\mathrm{Bi}(\mathrm{III})$ and $\mathrm{Pb}$ (II), so the analyzed sample was spiked with $\mathrm{Bi}(\mathrm{III})$ and $\mathrm{Pb}(\mathrm{II})$. Three replicate determinations using the standard addition method gave the average recovery values between 95.5 and $98.6 \%$ for $\mathrm{Bi}(\mathrm{III})$ with relative standard deviation between 6.0 and $6.7 \%$ and 94.2 and $97.0 \%$ for $\mathrm{Pb}(\mathrm{II})$ with relative standard deviation between 5.8 and $7.3 \%$. The typical voltammograms obtained in the course of this analysis are presented in Figure 5.

\section{Conclusion}

This work presents a new, simple, fast, and inexpensive procedure for the simultaneous determination of bismuth and lead ions. The adsorptive stripping voltammetry using cupferron as a complexing agent and renewable mercury film silver based electrode as a working electrode was successfully employed. The method offers low detection limits equal to $6.7 \times 10^{-10} \mathrm{~mol} \mathrm{~L}^{-1}$ and $8.8 \times 10^{-10} \mathrm{~mol} \mathrm{~L}^{-1}$ for Bi(III) and $\mathrm{Pb}(\mathrm{II})$, respectively, with good relative standard deviations below $5 \%$. The validity of the method was very successful, as it was shown by the analysis of wastewater certified reference material SPS-WW1. In case that the analyzed sample contains a large concentration of organic compounds the preliminary 
mixing with Amberlite XAD-7 resin should be performed. An important advantage of the proposed procedure is the fact that no deaeration of the solution is necessary, which makes it easy to use under laboratory and field conditions.

\section{Conflicts of Interest}

The authors declare that they have no conflicts of interest.

\section{References}

[1] C. Locatelli, "Metal Analysis in Real Matrices. Simultaneous Voltammetric Determination of Copper and Antimony in Alloys," Electroanalysis, vol. 9, no. 7, pp. 560-563, 1997.

[2] C. Pérez-Ràfols, N. Serrano, J. M. Díaz-Cruz, C. Ariño, and M. Esteban, "Glutathione modified screen-printed carbon nanofiber electrode for the voltammetric determination of metal ions in natural samples," Talanta, vol. 155, pp. 8-13, 2016.

[3] Y. Guo, N. Huang, B. Yang et al., "Hybrid diamond/graphite films as electrodes for anodic stripping voltammetry of trace $\mathrm{Ag}+$ and Cu2+," Sensors and Actuators B: Chemical, vol. 231, pp. 194-202, 2016.

[4] M. O. Oyagi, J. O. Onyatta, G. N. Kamau, and P. M. Guto, "Validation of the polyacrylic acid/glassy carbon differential pulse anodic stripping voltammetric sensor for simultaneous analysis of lead(II), cadmium(II) and cobalt(II) ions," International Journal of Electrochemical Science, vol. 11, no. 5, pp. 3852-3861, 2016.

[5] G. K. Çelik, A. F. Üzdürmez, A. Erkal, E. Kılıç, A. O. Solak, and Z. Üstündağ, "3,8-Diaminobenzo[c]Cinnoline Derivatived Graphene Oxide Modified Graphene Oxide Sensor for the Voltammetric Determination of $\mathrm{Cd} 2+$ and $\mathrm{Pb} 2+$," Electrocatalysis, vol. 7, no. 3, pp. 207-214, 2016.

[6] S. T. Palisoc, M. T. Natividad, N. M. D. C. Martinez, R. M. A. Ramos, and K. A. Y. Kaw, "Fabrication and electrochemical study of $[\mathrm{Ru}(\mathrm{NH} 3) 6] 3+/$ Nafion modified electrodes for the determination of trace amounts of $\mathrm{Pb} 2+, \mathrm{Cd} 2+$, and $\mathrm{Zn} 2+$ via anodic stripping voltammetry," E-Polymers, vol. 16, no. 2, pp. 117-123, 2016.

[7] B. Gadgil, P. Damlin, E. Dmitrieva, T. Ääritalo, and C. Kvarnström, "Exploring amide linkage in a polyviologen derivative towards simultaneous voltammetric determination of $\mathrm{Pb}$ (II), $\mathrm{Cu}(\mathrm{II})$ and $\mathrm{Hg}(\mathrm{II})$ ions," Electrochimica Acta, vol. 192, pp. 482488, 2016.

[8] A. Afkhami, M. Soltani-Shahrivar, H. Ghaedi, and T. Madrakian, "Construction of Modified Carbon Paste Electrode for Highly Sensitive Simultaneous Electrochemical Determination of Trace Amounts of Copper (II) and Cadmium (II)," Electroanalysis, vol. 28, no. 2, pp. 296-303, 2016.

[9] A. Koper and M. Grabarczyk, "Simultaneous voltammetric determination of trace bismuth(III) and cadmium(II) in water samples by adsorptive stripping voltammetry in the presence of cupferron," Journal of Electroanalytical Chemistry, vol. 681, pp. $1-5,2012$.

[10] M. Grabarczyk and A. Koper, "Simultaneous quantification of $\mathrm{Bi}(\mathrm{III})$ and $\mathrm{U}(\mathrm{VI})$ in environmental water samples with a complicated matrix containing organic compounds," Environmental Monitoring and Assessment, vol. 185, no. 7, pp. 5515-5522, 2013.

[11] M. Grabarczyk and A. Koper, "Simultaneous Determination of Trace Uranium(VI) and Cadmium(II) by Adsorptive Stripping Voltammetry in the Presence of Cupferron as a Complexing Agent," Electroanalysis, vol. 24, no. 4, pp. 907-910, 2012.
[12] E. Shams, H. Abdollahi, and R. Hajian, "Simultaneous determination of copper and bismuth by anodic stripping voltammetry using H-point standard addition method with simultaneous addition of analytes," Electroanalysis, vol. 17, no. 17, pp. 15891594, 2005.

[13] M. B. Gholivand and A. A. Romiani, "Application of adsorptive stripping voltammetry to the simultaneous determination of bismuth and copper in the presence of nuclear fast red," Analytica Chimica Acta, vol. 571, no. 1, pp. 99-104, 2006.

[14] S. S. Khaloo, A. A. Ensafi, and T. Khayamian, "Determination of bismuth and copper using adsorptive stripping voltammetry couple with continuous wavelet transform," Talanta, vol. 71, no. 1, pp. 324-332, 2007.

[15] E. Hasdemir and K. Karaboduk, "Simultaneous determination of bismuth and copper by square wave voltammetry in the presence of ethylenediaminetetraacedic acid," Gazi University Journal of Science, vol. 23, no. 1, pp. 33-39, 2010.

[16] R. Hajian and E. Shams, "Application of adsorptive stripping voltammetry to the determination of bismuth and copper in the presence of morin," Analytica Chimica Acta, vol. 491, no. 1, pp. 63-69, 2003.

[17] A. Babaei, E. Shams, and A. Samadzadeh, "Simultaneous determination of copper, bismuth and lead by adsorptive stripping voltammetry in the presence of thymolphthalexone," Analytical Sciences, vol. 22, no. 7, pp. 955-959, 2006.

[18] F. Shemirani, M. Baghdadi, M. Ramezani, and M. R. Jamali, "Determination of ultra trace amounts of bismuth in biological and water samples by electrothermal atomic absorption spectrometry (ET-AAS) after cloud point extraction," Analytica Chimica Acta, vol. 534, no. 1, pp. 163-169, 2005.

[19] Y.-H. Sung and S.-D. Huang, "On-line preconcentration system coupled to electrothermal atomic absorption spectrometry for the simultaneous determination of bismuth, cadmium, and lead in urine," Analytica Chimica Acta, vol. 495, no. 1-2, pp. 165-176, 2003.

[20] E. M. Saad, M. S. El-Shahwai, H. Saleh, and A. A. El-Asmy, "Studies on bismuth(III) complexes of ligands containing nitrogen/sulfur and extractive procedure for determination of Bi(III)," Transition Metal Chemistry, vol. 32, no. 2, pp. 155-162, 2007.

[21] D. W. Thomas, Metals and Their Compounds in the Environment, VCH, Weinheim, Germany, 1991.

[22] S.-I. Itoh, S. Kaneco, K. Ohta, and T. Mizuno, "Determination of bismuth in environmental samples with $\mathrm{Mg}-\mathrm{W}$ cell-electrothermal atomic absorption spectrometry," Analytica Chimica Acta, vol. 379, no. 1-2, pp. 169-173, 1999.

[23] M. Ahamed and M. K. J. Siddiqui, "Environmental lead toxicity and nutritional factors," Clinical Nutrition, vol. 26, no. 4, pp. 400-408, 2007.

[24] M. Jamaluddin Ahmed and M.-A. Mamun, "Spectrophotometric determination of lead in industrial, environmental, biological and soil samples using 2,5-dimercapto-1,3,4-thiadiazole," Talanta, vol. 55, no. 1, pp. 43-54, 2001.

[25] S. H. Abdel-Halim, A. M. A. Shehata, and M. F. El-Shahat, "Removal of lead ions from industrial waste water by different types of natural materials," Water Research, vol. 37, no. 7, pp. 1678-1683, 2003.

[26] Z. Cheng and K. A. Foland, "Lead isotopes in tap water: Implications for $\mathrm{Pb}$ sources within a municipal water supply system," Applied Geochemistry, vol. 20, no. 2, pp. 353-365, 2005. 
[27] S. Moyano, J. A. Gásquez, R. Olsina, E. Marchevsky, and L. D. Martinez, "Pre-concentration system for bismuth determination in urine using FI-ICP-AES with ultrasonic nebulization," Journal of Analytical Atomic Spectrometry, vol. 14, no. 2, pp. 259262, 1999.

[28] H. Li, B. M. Keohane, H. Sun, and P. J. Sadler, "Determination of bismuth in serum and urine by direct injection nebulization inductively coupled plasma mass spectrometry," Journal of Analytical Atomic Spectrometry, vol. 12, no. 10, pp. 1111-1114, 1997.

[29] J. Kokšal, V. Synek, and P. Janoš, "Extraction-spectrometric determination of lead in high-purity aluminium salts," Talanta, vol. 58, no. 2, pp. 325-330, 2002.

[30] G. E. M. Hall, A. I. MacLaurin, J. C. Pelchat, and G. Gauthier, "Comparison of the techniques of atomic absorption spectrometry and inductively coupled plasma mass spectrometry in the determination of $\mathrm{Bi}, \mathrm{Se}$ and Te by hydride generation," Chemical Geology, vol. 137, no. 1-2, pp. 79-89, 1997.

[31] S. Cadore, A. P. Dos Anjos, and N. Baccan, "Determination of bismuth in urine and prescription medicines using atomic absorption with an on-line hydride generation system," Analyst, vol. 123, no. 8, pp. 1717-1719, 1998.

[32] İ. Kula, Y. Arslan, S. Bakirdere, S. Titretir, E. Kendüzler, and O. Y. Ataman, "Determination and interference studies of bismuth by tungsten trap hydride generation atomic absorption spectrometry," Talanta, vol. 80, no. 1, pp. 127-132, 2009.

[33] J. S. Barin, F. R. Bartz, V. L. Dressler, J. N. G. Paniz, and É. M. M. Flores, "Microwave-induced combustion coupled to flame furnace atomic absorption spectrometry for determination of cadmium and lead in botanical samples," Analytical Chemistry, vol. 80, no. 23, pp. 9369-9374, 2008.

[34] S. Dadfarnia, A. M. Salmanzadeh, and A. M. H. Shabani, "A novel separation/preconcentration system based on solidification of floating organic drop microextraction for determination of lead by graphite furnace atomic absorption spectrometry," Analytica Chimica Acta, vol. 623, no. 2, pp. 163-167, 2008.

[35] E. J. Dos Santos, A. B. Herrmann, V. L. A. Frescura, B. Welz, and A. J. Curtius, "Determination of lead in sediments and sewage sludge by on-line hydride-generation axial-view inductivelycoupled plasma optical-emission spectrometry using slurry sampling," Analytical and Bioanalytical Chemistry, vol. 388, no. 4, pp. 863-868, 2007.

[36] B. Baś, "Refreshable mercury film silver based electrode for determination of chromium(VI) using catalytic adsorptive stripping voltammetry," Analytica Chimica Acta, vol. 570, no. 2, pp. 195-201, 2006.

[37] A. Koper and M. Grabarczyk, "Electrochemical determination of bismuth with use of a $\mathrm{Bi}$ (III)-cupferron complexation system and elimination of interferences connected with the presence of organic substances in natural samples," Journal of Electroanalytical Chemistry, vol. 663, no. 2, pp. 67-71, 2011.

[38] M. Grabarczyk, "Sensitive adsorptive stripping voltammetric method for direct determination of trace concentration of lead in the presence of cupferron in natural water samples," International Journal of Environmental Analytical Chemistry, vol. 93, no. 9, pp. 1008-1018, 2013.

[39] M. Grabarczyk and A. Koper, "Selective, sensitive and economical method for the adsorptive voltammetric determination of trace amounts of $\mathrm{Mo}(\mathrm{VI})$ in organic matter rich environmental samples," Talanta, vol. 84, no. 2, pp. 393-399, 2011.

[40] M. Grabarczyk and A. Koper, "Adsorptive stripping voltammetry of uranium: Elimination of interferences from surface active substances and application to the determination in natural water samples," Analytical Methods, vol. 3, no. 5, pp. 1046-1050, 2011.

[41] M. Grabarczyk and A. Koper, "Direct Determination of Cadmium Traces in Natural Water by Adsorptive Stripping Voltammetry in the Presence of Cupferron as a Chelating Agent," Electroanalysis, vol. 24, no. 1, pp. 33-36, 2012.

[42] M. Grabarczyk and C. Wardak, "A new voltammetric strategy for sensitive and selective determination of gallium using cupferron as a complexing agent," Journal of Environmental Science and Health - Part A Toxic/Hazardous Substances and Environmental Engineering, vol. 49, no. 10, pp. 1142-1148, 2014. 

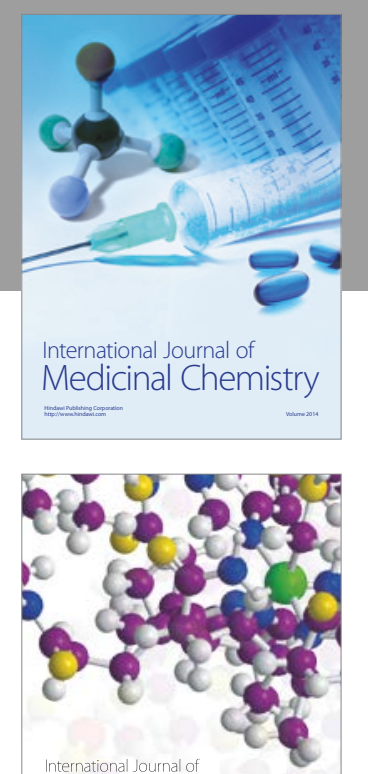

Carbohydrate Chemistry

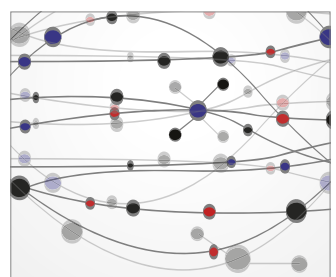

The Scientific World Journal
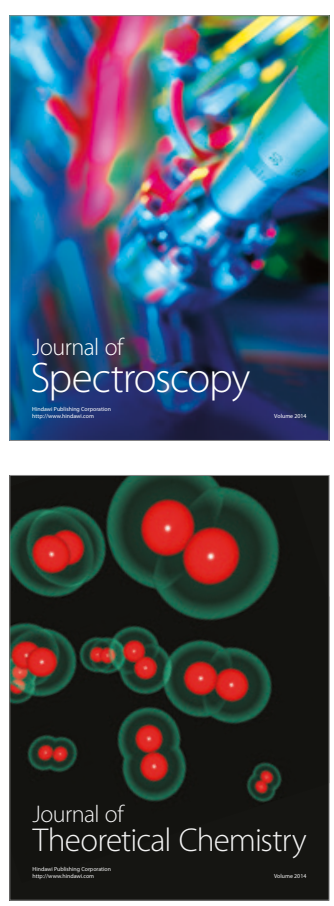
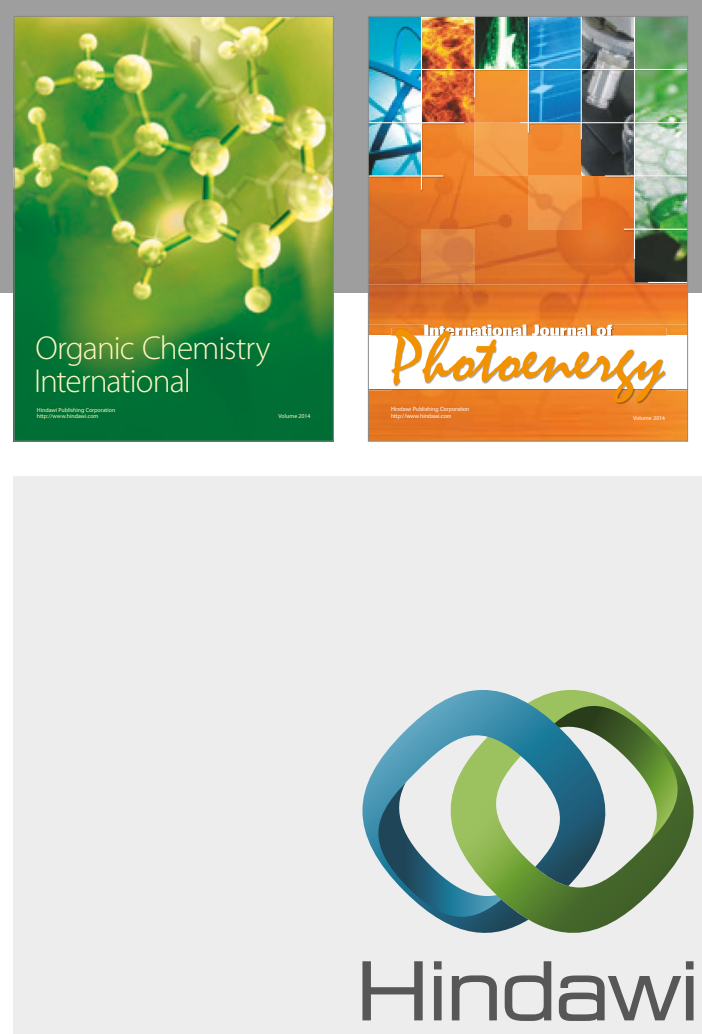

Submit your manuscripts at

https://www.hindawi.com

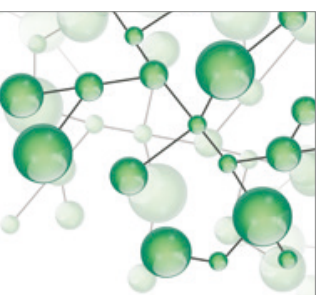

International Journal of

Inorganic Chemistry

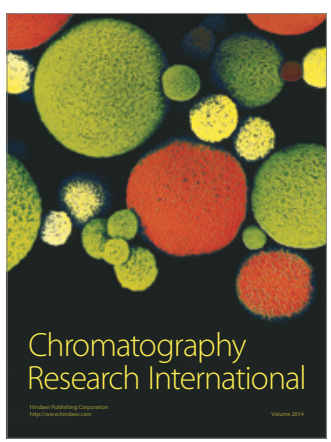

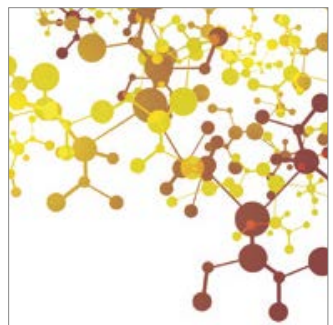

Applied Chemistry
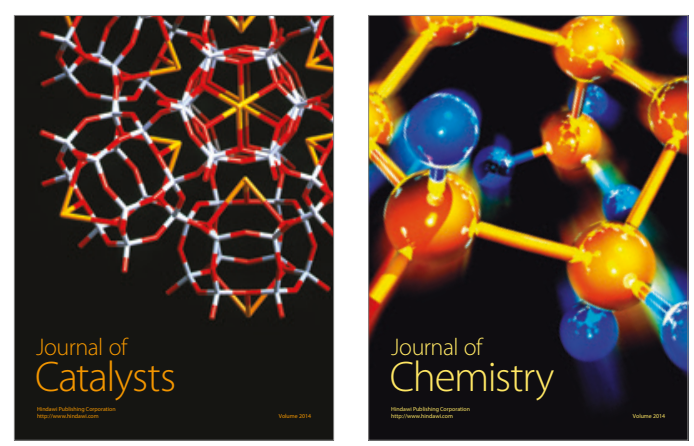
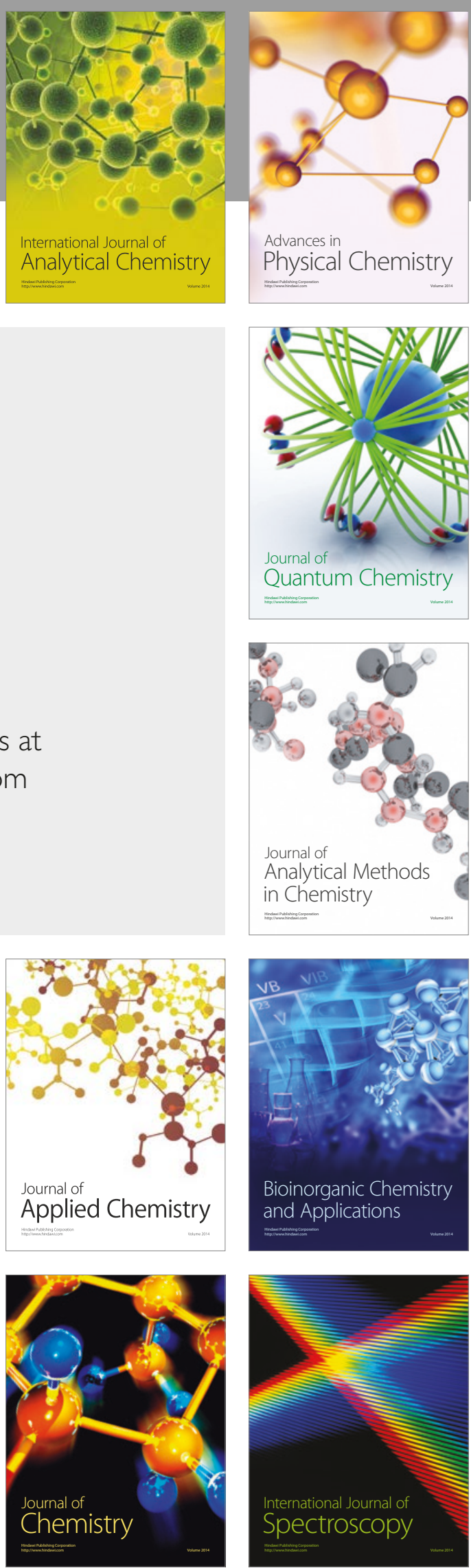